\title{
APPLICATION GRAPHOANALYTICAL METHOD FOR ASSESSING THE CHANGE IN THE SPEED OF MOVEMENT OF VEHICLES MEANS AFTER REPAIR OF HIGHWAYS
}

\author{
Alexey Kamenchukov* \\ Pacific National University, Russian Federation
}

The article deals with the issues of improving the quality of repair and reconstruction of highways design works. The main criterion of assessing the effectiveness of work is the hypothesis that the speed of vehicles depends directly on the condition of the road pavement and the elimination of defects leads to an increase of the traffic speed. The field research was made to measure the speed of vehicles on road sections before and after repair works. The criteria and factors influencing the change in the road speed are determined. The graphic-analytical method is proposed for estimating the service performance of highways based on the prediction of the change of speed.

Key words: transport, road capacity, roadtraffic quality, motor-road, estimated speed, actualspeed, defects, deformations

\section{INTRODUCTION}

Quality and safe road traffic is primarily characterized by the operational condition of road pavement, that is, the degree to which the main time variant indicators of road pavement meet the requirements: speed, safety, comfort and continuity of traffic (Sayers 1986). Such characteristics of the pavement as strength, smoothness, road adhesion, wear rate and so on are responsible for these properties (Rosavtodor 2002; Kamenchukov, Yarmolinskiy, Krivko 2016).

Obviously, the most significant indicator, from the standpoint of effective use of highways, is the provision of speed, as the intensity and volume of freight and passenger traffic, transportation costs, the cost of most materials, products, speed of first aid and so on depend the road speed.

In the design and construction of roads, operational parameters are determined for the estimated speed. According to the regulatory documents concerning road construction, estimated speed is considered the highest possible (in terms of stability and safety) speed of single vehicles under normal weather conditions and adhesion of car tires, which in the most unfavorable sections of the track corresponds to the maximum permissible values of road elements. However, this characteristic of the speed is not identical to the actual conditions of traffic on the operated roads.

As during the operation of motor roads the pavement wears out, defects and deformations occur, the strength decreases, the smoothness and tire grip of the vehicle deteriorate, the driver becomes more difficult or even impossible to move on the road at an estimated speed (Khan, Norton, Keegan, Gould, Jacques 2017; Onyango, Merabti, Owino, Fomunung, Wu 2018). In addition, in most cases the actual speed of traffic is not equal to the estimated speed, even on newly constructed or repaired sections of the road (Kamenchukov 2015). It is clear that on the repaired section of the road the speed of traffic increases compared to the speed of traffic before the road repair, but it is generally unknown how this affects the efficiency of road use. Therefore, the purpose of this research is to establish the dependencies between the quality of the road pavement and the speed of traffic on the roads, and to determine the characteristics and criteria of assessing the efficiency road repair and reconstruction.

\section{Modern methods of assessing the service performance of road pavement}

In Europe and the USA, the HDM-3 technique is usually used for the diagnosis and assessment of the performance properties of roads, for the timely identification of problem areas and the evaluation of the efficiency of road repair works (Chen, Lin 2013; Khan, Higgins 2015; Yogesh, Jain, Devesh 2016). This technique has proven itself and is actively used to monitor the condition of roads, but there must be a high road density for its effective application in the country, that is, a well-developed transport infrastructure throughout the country. For example, in Europe, the road density is more than $1,500 \mathrm{~km}$ per $1,000 \mathrm{~km}^{2}$, in the United States more than $650 \mathrm{~km}$ per $1,000 \mathrm{~km}^{2}$, and in the Russian Federation less than $100 \mathrm{~km}$ per $1,000 \mathrm{~km}^{2}$.

The road density in Russia is low primarily due to the large territory of the country and significant distances between the territorial and regional centers (an average of 100 to $250 \mathrm{~km}$ ). This factor makes it impossible to implement the HDM-3 methodology universally on the territory of the Russian Federation and emphasizes the need to develop predictive methods for evaluating the efficiency of road repair works.

At the present time the operational condition of roads and road pavements is determined based on the results of diagnosis and photo and video certification (Yarmo 
linsky, Lopashuk, V., Lopashuk A. 2014; Surbakti, Doan 2018), as well as detailed instrumental studies of problem sections (Rosavtodor 2002).

In the Russian Federation, European countries and the United States, specialized mobile road laboratories based on a minibus or a pickup are used to diagnose and certify roads. In addition, even more often drones and unmanned aerial vehicles - quadcopters - are used in road inspection (Cubero-Fernandez, Rodriguez-Lozano, Villatoro, Olivares, Palomares 2017).

Based on the results of the diagnostics and on the photo and video materials, defects in the road pavement are recognized and systematized, using special methods of processing 3D images (Rosavtodor 2002; Ouma, Hahn 2017).

In Russia the technique developed by Professor A. P. Vasilyev is used for the evaluation of transport and operational condition of highways, i.e. the road condition is estimated with the resulting value of the coefficient of the calculated velocity (CCV). Also for techno-economic comparison of variants of pavement one can apply the methodology which takes into account the cost of operation and repair of road pavements for the full overhaul service life, considering the residual value of the pavement (Rosavtodor 2002; Rosavtodor 2013).

In Europe and the United States the Pavement Condition Index $(\mathrm{PCl})$ is used to assess the operational condition of the road surface which reflects the level of defects in the pavement (Radovskiy 2006). The cost of repair depends on the methods and means of the work done and is provided with $1 \mathrm{~m}^{2}$ of repaired pavement (Kamenchukov, Yarmolinskiy 2013).

In addition, in the international practice such indicators as the International Roughness Index (IRI) (International Roughness Index) and the Surface Strength Index (SSI) are calculated for assessing the operational condition of the road pavement (Samuel Labi, Kumares C. Sinha 2003). However, the above mentioned indicators and methods are not intended for forecasting and evaluation of the service performance of the road pavement after the repair and reconstruction of roads.

\section{Measuring the speed}

The speed of vehicles was determined on the roads with black top surface located in the Khabarovsk Krai of the Russian Federation. The road sections with various types of defects were selected for the research: cracks, potholes.

List of examined sections of highways:

1. Khabarovsk - Lidoga village - Vanino workers settlement with access to the city of Komsomolsk-on-Amur on the 102-119km section (sections 1, 2, 4, 5, 7, 10, 13, 14, 15, 19, 20, 24, 28);

2. Bypass of the Krasnaya Rechka village - Kazakevichevo village on the $12-17 \mathrm{~km}$ section (sections 6,11 , $12,16,17,21,25,29,30)$;
3. Khabarovsk - Ilyinka village - Rakitnoye village - Garovka village - Gorky settlement on the $8-11 \mathrm{~km}$ section (sections 3, 8, 9, 18, 22, 23, 26, 27, 31).

\section{Conditions and methods of measurement}

For the period from 2016 to 2017 on the roads of the Khabarovsk Krai the measuring of the speed of traffic was made using video monitoring on the road sections before and after the road pavement repairs. In total, 31 sections of motor roads with the following defects of pavement were examined, according to the classification of Russian Road Research Institute:

- Cross and longitudinal cracks, with opening width up to $2 \mathrm{~mm}$;

- $\quad$ Cross and longitudinal cracks, with opening width up to $5 \mathrm{~mm}$;

- Cross and longitudinal cracks, with opening width up to $10 \mathrm{~mm}$;

- Cross and longitudinal cracks, with opening width more than $10 \mathrm{~mm}$;

- Single potholes on pavement containing organic binder (distance between potholes more than 20m);

- Infrequent potholes in the same cases (distance 4-10m);

Frequent potholes in the same cases (distance 1-4m). Measurements of the speed were made in the summer, with an air temperature of at least $20^{\circ} \mathrm{C}$, clear visibility, without rain and fog, in a relatively straight terrain without steep ascents, descents and rounds. A segment of 100$150 \mathrm{~m}$ suitable for one of the above mentioned defects of the pavement was chosen on the section of the terrain. The measurements were made using the following equipment:

- Mobile road laboratory on the basis of a minibus "Gazel";

- Universal road measuring rod KP-231S;

- Fixed video camera.

To measure the speed on the section with the detected defect, wand markers were installed that denoted the boundaries of the section with a length of $100-150 \mathrm{~m}$. The speed was measured at the areas with free (level A) or partially connected (level B) traffic, with the load factor $Z$ not more than 0.45 , and was determined by the standard formula:

$V=3.6 \mathrm{~L} / \mathrm{t}$

where $L$ is the distance traveled by the car, meters; $t$ is the travel time, seconds.

At least 400 measurements of the speed were made in one section. The equipment was installed without interfering the free traffic of vehicles and causing the drivers' natural reaction caution when a potential obstacle arises on the roadside. As the measurement of the speed was done for 2-4 days in one section, a two-level binding was used to fix the section on the terrain: firstly the picket 
fixation of the section in relation to the existing kilometer road signs (white paint on the roadside stabilized with asphalt concrete), secondly coordinates of start and end points for GPS and GLONASS were determined.

\section{Analysis and evaluation of measurement results}

For the convenience of data processing and systematization, it was decided to group the results into speed intervals of $10 \mathrm{~km} / \mathrm{h}$. The weighted average speed of each section and the total weighted average speed of all sections with the same defects of the pavement were determined. The results of the measurements systematized according to this principle are presented in Table 1.

Table 1: The speed of vehicles before road repair

\begin{tabular}{|c|c|c|c|c|c|c|c|c|c|c|c|c|}
\hline \multirow{2}{*}{ Section } & \multicolumn{11}{|c|}{ Intervals of the speed measurements $(\mathrm{km} / \mathrm{h})$ and the number of measurements in the interval } & \multirow{2}{*}{$\begin{array}{l}\text { Average } \\
\text { speed, } \\
\mathrm{km} / \mathrm{h}\end{array}$} \\
\hline & {$[30 \div 40)$} & {$[40 \div 50)$} & {$[50 \div 60)$} & {$[60 \div 70)$} & {$[70 \div 80)$} & {$[80 \div 90)$} & {$[90 \div 100)$} & {$[100 \div 110$} & {$[110 \div 120)$} & {$[120 \div 130)$} & {$[130 \div 140]$} & \\
\hline \multicolumn{13}{|c|}{ Cross and longitudinal cracks, with opening width up to $2 \mathrm{~mm}$} \\
\hline № 1 & 0 & 0 & 5 & 29 & 108 & 214 & 72 & 21 & 7 & 3 & 1 & 84.37 \\
\hline № 2 & 0 & 2 & 2 & 24 & 72 & 154 & 42 & 22 & 6 & 2 & 0 & 84.33 \\
\hline № 3 & 0 & 2 & 2 & 24 & 76 & 150 & 42 & 24 & 4 & 2 & 0 & 84.15 \\
\hline Total & 0 & 4 & 9 & 77 & 256 & 518 & 156 & 67 & 17 & 7 & 1 & 84.29 \\
\hline \multicolumn{13}{|c|}{ Cross and longitudinal cracks, with opening width up to $5 \mathrm{~mm}$} \\
\hline № 4 & 0 & 0 & 3 & 26 & 106 & 225 & 67 & 23 & 6 & 3 & 1 & 84.59 \\
\hline № 5 & 0 & 0 & 3 & 37 & 102 & 222 & 65 & 23 & 5 & 3 & 0 & 83.98 \\
\hline № 6 & 0 & 1 & 4 & 22 & 74 & 150 & 50 & 20 & 5 & 0 & 0 & 84.12 \\
\hline Total & 0 & 1 & 10 & 85 & 282 & 597 & 182 & 66 & 16 & 6 & 1 & 84.24 \\
\hline \multicolumn{13}{|c|}{ Cross and longitudinal cracks, with opening width up to $10 \mathrm{~mm}$} \\
\hline № 7 & 0 & 1 & 5 & 35 & 104 & 233 & 56 & 19 & 7 & 0 & 0 & 83.31 \\
\hline № 8 & 0 & 3 & 5 & 35 & 115 & 217 & 58 & 19 & 5 & 3 & 0 & 83.07 \\
\hline № 9 & 0 & 0 & 6 & 34 & 74 & 162 & 48 & 12 & 6 & 0 & 0 & 82.96 \\
\hline Total & 0 & 4 & 16 & 104 & 293 & 612 & 162 & 50 & 18 & 3 & 0 & 83.13 \\
\hline \multicolumn{13}{|c|}{ Cross and longitudinal cracks, with opening width more than $10 \mathrm{~mm}$} \\
\hline № 10 & 0 & 3 & 3 & 35 & 102 & 224 & 62 & 17 & 7 & 5 & 2 & 84.00 \\
\hline № 11 & 0 & 4 & 4 & 34 & 70 & 168 & 46 & 10 & 4 & 2 & 0 & 82.67 \\
\hline № 12 & 0 & 2 & 4 & 38 & 66 & 164 & 48 & 13 & 4 & 2 & 1 & 83.16 \\
\hline Total & 0 & 9 & 11 & 107 & 238 & 556 & 156 & 40 & 15 & 9 & 3 & 83.35 \\
\hline \multicolumn{13}{|c|}{ Single potholes on pavement containing organic binder (distance between potholes more than $20 \mathrm{~m}$ ) } \\
\hline № 13 & 0 & 3 & 27 & 84 & 161 & 105 & 43 & 11 & 2 & 0 & 0 & 76.95 \\
\hline № 14 & 0 & 2 & 22 & 80 & 182 & 98 & 41 & 10 & 1 & 0 & 0 & 76.93 \\
\hline № 15 & 0 & 4 & 25 & 88 & 166 & 102 & 39 & 12 & 0 & 0 & 0 & 76.52 \\
\hline № 16 & 0 & 3 & 26 & 76 & 171 & 101 & 45 & 10 & 3 & 1 & 0 & 77.32 \\
\hline № 17 & 0 & 2 & 21 & 82 & 179 & 99 & 39 & 12 & 2 & 0 & 0 & 77.09 \\
\hline № 18 & 0 & 1 & 23 & 84 & 182 & 95 & 41 & 9 & 1 & 0 & 0 & 76.73 \\
\hline Total & 0 & 15 & 144 & 494 & 1041 & 600 & 248 & 64 & 9 & 1 & 0 & 76.92 \\
\hline \multicolumn{13}{|c|}{ Single potholes on pavement containing organic binder (distance between potholes $10-20 \mathrm{~m}$ ) } \\
\hline № 19 & 0 & 4 & 39 & 92 & 175 & 77 & 39 & 5 & 2 & 0 & 0 & 74.91 \\
\hline № 20 & 0 & 6 & 38 & 95 & 174 & 78 & 35 & 6 & 1 & 0 & 0 & 74.57 \\
\hline № 21 & 0 & 5 & 40 & 99 & 168 & 79 & 40 & 2 & 0 & 0 & 0 & 74.34 \\
\hline № 22 & 0 & 4 & 41 & 98 & 172 & 73 & 38 & 5 & 2 & 0 & 0 & 74.54 \\
\hline № 23 & 0 & 2 & 37 & 93 & 176 & 80 & 37 & 7 & 1 & 0 & 0 & 75.14 \\
\hline Total & 0 & 21 & 195 & 477 & 865 & 387 & 189 & 25 & 6 & 0 & 0 & 74.70 \\
\hline
\end{tabular}




\begin{tabular}{|c|c|c|c|c|c|c|c|c|c|c|c|c|}
\hline \multirow{2}{*}{ Section } & \multicolumn{11}{|c|}{ Intervals of the speed measurements $(\mathrm{km} / \mathrm{h})$ and the number of measurements in the interval } & \multirow{2}{*}{$\begin{array}{l}\text { Average } \\
\text { speed, } \\
\mathrm{km} / \mathrm{h}\end{array}$} \\
\hline & {$[30 \div 40)$} & {$[40 \div 50)$} & {$[50 \div 60)$} & {$[60 \div 70)$} & {$[70 \div 80)$} & {$[80 \div 90)$} & {$[90 \div 100)$} & {$[100 \div 110)$} & {$[110 \div 120)$} & {$[120 \div 130)$} & {$[130 \div 140]$} & \\
\hline \multicolumn{13}{|c|}{ Infrequent potholes in the same cases (distance $4-10 \mathrm{~m}$ ) } \\
\hline № 24 & 2 & 26 & 87 & \begin{tabular}{|l|}
147 \\
\end{tabular} & \begin{tabular}{|l|}
94 \\
\end{tabular} & 58 & 12 & \begin{tabular}{|l|}
3 \\
\end{tabular} & \begin{tabular}{|l|}
1 \\
\end{tabular} & 0 & 0 & 67.75 \\
\hline № 25 & 3 & 20 & 92 & 150 & 91 & 60 & 13 & 1 & 0 & 0 & 0 & 67.63 \\
\hline № 26 & 0 & 31 & 91 & 144 & 93 & 59 & 10 & 2 & 0 & 0 & 0 & 67.24 \\
\hline № 27 & 0 & 27 & 85 & 155 & 89 & 63 & 9 & 2 & 0 & 0 & 0 & 67.59 \\
\hline Total & 5 & 104 & 355 & 596 & 367 & 240 & 44 & 8 & 1 & 0 & 0 & 67.55 \\
\hline \multicolumn{13}{|c|}{ Frequent potholes in the same cases (distance $1-4 \mathrm{~m}$ ) } \\
\hline № 28 & 12 & 68 & 167 & 105 & 62 & 24 & 1 & \begin{tabular}{|l|}
0 \\
\end{tabular} & \begin{tabular}{|l|}
0 \\
\end{tabular} & 0 & 0 & 59.86 \\
\hline № 29 & 11 & 72 & 175 & 99 & 60 & 20 & 2 & 0 & 0 & 0 & 0 & 59.40 \\
\hline № 30 & 5 & 79 & 150 & 109 & 65 & 25 & 4 & 2 & 0 & 0 & 0 & 60.72 \\
\hline № 31 & 10 & 71 & 169 & 102 & 59 & 26 & 2 & 0 & 0 & 0 & 0 & 59.90 \\
\hline Total & 38 & 290 & 661 & 415 & 246 & 95 & 9 & 2 & 0 & 0 & 0 & 59.97 \\
\hline
\end{tabular}

After elimination of defects in the examined sections of highways, a repeated measurement of the speed was made. The natural and climatic conditions of measuring the speed corresponded to the conditions before repair and restoration works if possible. As after repair and restoration works the motor road pavement must meet high (excellent) transport and operational requirements, which do not depend on the technique and technology of work execution, the methods of performing the work to eliminate the defects of the pavement were not taken into account in the research. The results of measurements of the speed are shown in Table 2.

Table 2: The speed of vehicles after road repair

\begin{tabular}{|c|c|c|c|c|c|c|c|c|c|c|c|c|}
\hline \multirow{2}{*}{ Section } & \multicolumn{11}{|c|}{ Intervals of the speed measurements $(\mathrm{km} / \mathrm{h})$ and the number of measurements in the interval } & \multirow{2}{*}{$\begin{array}{l}\text { Average } \\
\text { speed, } \\
\mathrm{km} / \mathrm{h}\end{array}$} \\
\hline & {$[30 \div 40)$} & {$[40 \div 50)$} & {$[50 \div 60)$} & {$[60 \div 70$} & {$[70 \div 80)$} & {$[80 \div 90)$} & {$[90 \div 100)$} & {$[100 \div 110)$} & {$[110 \div 120)$} & {$[120 \div 130)$} & {$[130 \div 140]$} & \\
\hline \multicolumn{13}{|c|}{ Cross and longitudinal cracks, with opening width up to $2 \mathrm{~mm}$} \\
\hline № 1 & 0 & 0 & 2 & 35 & 105 & 209 & 79 & 28 & 8 & 2 & 0 & 84.71 \\
\hline № 2 & 0 & 0 & 2 & 21 & 70 & 159 & 41 & 25 & 7 & 3 & 0 & 85.19 \\
\hline № 3 & 0 & 1 & 2 & 22 & 71 & 155 & 42 & 26 & 7 & 2 & 0 & 84.94 \\
\hline Total & 0 & 1 & 6 & 78 & 246 & 523 & 162 & 79 & 22 & 7 & 0 & 84.92 \\
\hline \multicolumn{13}{|c|}{ Cross and longitudinal cracks, with opening width up to $5 \mathrm{~mm}$} \\
\hline № 4 & 0 & 0 & 2 & 29 & 98 & 217 & 77 & 31 & 11 & 3 & 0 & 85.48 \\
\hline № 5 & 0 & 0 & 2 & 36 & 99 & 210 & 77 & 28 & 10 & 4 & 2 & 85.26 \\
\hline № 6 & 0 & 0 & 1 & 23 & 69 & 157 & 46 & 23 & 8 & 1 & 0 & 85.07 \\
\hline Total & 0 & 0 & 5 & 88 & 266 & 584 & 200 & 82 & 29 & 8 & 2 & 85.29 \\
\hline \multicolumn{13}{|c|}{ Cross and longitudinal cracks, with opening width up to $10 \mathrm{~mm}$} \\
\hline № 7 & 0 & 0 & 4 & 34 & 102 & 210 & 74 & 29 & 10 & 4 & 1 & 85.03 \\
\hline № 8 & 0 & 0 & 5 & 37 & 107 & 199 & 75 & 30 & 11 & 4 & 0 & 84.75 \\
\hline № 9 & 0 & 0 & 2 & 33 & 79 & 169 & 60 & 24 & 10 & 2 & 0 & 84.87 \\
\hline Total & 0 & 0 & 11 & 104 & 288 & 578 & 209 & 83 & 31 & 10 & 1 & 84.88 \\
\hline \multicolumn{13}{|c|}{ Cross and longitudinal cracks, with opening width more than $10 \mathrm{~mm}$} \\
\hline № 10 & 0 & 0 & 0 & 31 & \begin{tabular}{l|l}
97 \\
\end{tabular} & 212 & 79 & 32 & 10 & 4 & 3 & 85.97 \\
\hline № 11 & 0 & 1 & 2 & 31 & 81 & 164 & 64 & 22 & 10 & 3 & 1 & 85.06 \\
\hline № 12 & 0 & 1 & 3 & 30 & 77 & 168 & 65 & 21 & 11 & 2 & 1 & 85.08 \\
\hline Total & 0 & 2 & 5 & 92 & 255 & 544 & 208 & 75 & 31 & 9 & 5 & 85.41 \\
\hline \multicolumn{13}{|c|}{ Single potholes on pavement containing organic binder (distance between potholes more than $20 \mathrm{~m}$ ) } \\
\hline № 13 & 0 & 0 & 2 & 37 & 64 & 127 & 159 & 35 & 7 & 1 & 0 & 87.55 \\
\hline № 14 & 0 & 0 & 3 & 27 & 71 & 136 & 161 & 31 & 3 & 0 & 0 & 87.27 \\
\hline № 15 & 0 & 0 & 2 & 29 & 67 & 121 & 170 & 37 & 5 & 1 & 0 & 88.06 \\
\hline № 16 & 0 & 1 & 3 & 34 & 68 & 131 & 157 & 32 & 6 & 0 & 0 & 87.09 \\
\hline
\end{tabular}




\begin{tabular}{|c|c|c|c|c|c|c|c|c|c|c|c|c|}
\hline \multirow{2}{*}{ Section } & \multicolumn{11}{|c|}{ Intervals of the speed measurements $(\mathrm{km} / \mathrm{h})$ and the number of measurements in the interval } & \multirow{2}{*}{$\begin{array}{c}\text { Average } \\
\text { speed, } \\
\mathrm{km} / \mathrm{h}\end{array}$} \\
\hline & {$[30 \div 40)$} & {$[40 \div 50)$} & {$[50 \div 60)$} & {$[60 \div 70)$} & {$[70 \div 80)$} & {$[80 \div 90)$} & {$[90 \div 100)$} & {$[100 \div 110)$} & {$[110 \div 120)$} & {$[120 \div 130)$} & {$[130 \div 140]$} & \\
\hline № 17 & 0 & 0 & 1 & 32 & 64 & 129 & 169 & 33 & 4 & 0 & 0 & 87.69 \\
\hline № 18 & 0 & 0 & 2 & 30 & 66 & 134 & 154 & 38 & 6 & 2 & 0 & 87.88 \\
\hline Total & 0 & 1 & 13 & 189 & 400 & 778 & 970 & 206 & 31 & 4 & 0 & 87.59 \\
\hline \multicolumn{13}{|c|}{ Single potholes on pavement containing organic binder (distance between potholes $10-20 \mathrm{~m}$ ) } \\
\hline № 19 & 0 & 0 & 2 & 34 & 68 & 121 & 171 & 33 & 7 & 0 & 0 & 87.67 \\
\hline № 20 & 0 & 0 & 5 & 39 & 66 & 116 & 173 & 33 & 3 & 1 & 0 & 87.14 \\
\hline № 21 & 0 & 1 & 3 & 37 & 69 & 126 & 167 & 29 & 4 & 0 & 0 & 86.86 \\
\hline № 22 & 0 & 1 & 3 & 36 & 70 & 117 & 172 & 34 & 3 & 0 & 0 & 87.16 \\
\hline № 23 & 0 & 0 & 2 & 41 & 63 & 124 & 164 & 35 & 6 & 1 & 0 & 87.41 \\
\hline Total & 0 & 2 & 15 & 187 & 336 & 604 & 847 & 164 & 23 & 2 & 0 & 87.25 \\
\hline \multicolumn{13}{|c|}{ Infrequent potholes in the same cases (distance $4-10 \mathrm{~m}$ ) } \\
\hline № 24 & 0 & 1 & 5 & 41 & 66 & 117 & 175 & 33 & 2 & 0 & 0 & 86.82 \\
\hline № 25 & 0 & 0 & 4 & 40 & 64 & 124 & 160 & 39 & 7 & 2 & 0 & 87.53 \\
\hline № 26 & 0 & 0 & 7 & 39 & 69 & 122 & 161 & 35 & 5 & 2 & 0 & 86.96 \\
\hline № 27 & 0 & 1 & 3 & 45 & 65 & 120 & 170 & 31 & 4 & 1 & 0 & 86.82 \\
\hline Total & 0 & 2 & 19 & 165 & 264 & 483 & 666 & 138 & 18 & 5 & 0 & 87.03 \\
\hline \multicolumn{13}{|c|}{ Frequent potholes in the same cases (distance 1-4m) } \\
\hline № 28 & 0 & 0 & 2 & 38 & 66 & 132 & 169 & 29 & 2 & 0 & 0 & 86.95 \\
\hline № 29 & 0 & 0 & 3 & 41 & 70 & 129 & 159 & 31 & 4 & 1 & 0 & 86.74 \\
\hline № 30 & 0 & 0 & 2 & 36 & 68 & 134 & 163 & 33 & 2 & 0 & 0 & 87.04 \\
\hline № 31 & 0 & 1 & 4 & 39 & 72 & 131 & 159 & 30 & 2 & 0 & 0 & 86.35 \\
\hline Total & 0 & 1 & 11 & 154 & 276 & 526 & 650 & 123 & 10 & 1 & 0 & 86.77 \\
\hline
\end{tabular}

From the analysis of the data presented in Tables 1 and 2 it is clear that the elimination of defects on the pavement leads to an increase in the speed of the vehicles in the sector, that is, leads to the approximation of the actual weighted average speed to the estimated speed. Nevertheless, in order to establish the relationship between the speed in the section before and after repair work more accurately, it is necessary to check the sample for the normally distributed random variable (the actual speed of one car).

It is necessary to run a statistical test of the hypothesis that the samples in question are normally distributed. To do this, we accept the basic or null hypothesis that the considered samples belong to the normal law of distribution. Then, with the help of special statistical criteria, we find out whether the sample data matches the accepted hypothesis or not. This method of investigating statistical variables is one of the main methods of estimating the hypothesis belonging to the normal law of distribution (Venttsel, Ovcharov 1991).

As the random variable is limited by a sample from some general population in our research, and the volume of statistical tests is always limited, it is important to choose the distribution law correctly in order to obtain correct results. A limited number of statistical tests affects the type and shape of the distribution curve. The processing of statistical values was performed in the program STATISTICA.
To construct a histogram of the distribution of the variation of a random variable, we determine the class length (length of the interval $D_{N}$ by the Sturges formula (Venttsel, Ovcharov 1991):

$D_{N}=\frac{x_{\max }-x_{\min }}{1+3.32 \lg (N)}$

where $x_{\max }$ and $x_{\min }$ are respectively the maximum and minimum values in the sample; $\mathrm{N}$ is the number of measurements or sample size.

The ordinary moments were determined for the statistical processing of a series of sample. The h-order ordinary moment is equal to the sum of the products of each deviation of $x$, taken raised to the power $h$, by the corresponding frequency $n_{j}$ divided by the sum of all frequencies $n$ :

$m_{h}=\sum_{j=1}^{k}\left(x_{j}^{k} n_{j}\right) / n$

where $k$ is the number of digits of the series under consideration.

If instead of the deviations $x$ we use the values of the random variable $X_{i}$, we get the mathematical expectation of the random variable:

$M[X]=\sum_{j=1}^{k}\left(X_{j} n_{j}\right) / n$ 
Physically, the first moment means the center of mass of the distribution. The second moment means the moment of inertia. The ordinary moments in themselves do not have much applied value. They are generally auxiliary values for the calculation of a moment about mean. The moments about mean are calculated by the formula:

$\mu_{h}=\sum_{j=1}^{k}\left(\left(x_{j}-m_{1}\right)^{h} n_{j}\right) / n$

The second moment about mean $\mu_{2}$ has practical importance as it determines the variance of the random variable $\sigma^{2}$. The variance of a random variable is a characteristic of the scattering, the spread of a random variable near its mathematical expectation. Taking a positive square root of the variance, we get the mean square deviation or standard deviation of the random variable:

$\sigma[X]=+\sqrt{\mu_{2}}$

An example of the division of samples into classes for one measuring of a random variable is given in Table 3.

Table 3: Arranging of speed of vehicles on section №1 before repair work

\begin{tabular}{|c|c|c|c|c|c|c|}
\hline \multirow{2}{*}{$\begin{array}{c}\text { Interval } \\
\text { number, } \\
\mathrm{k}\end{array}$} & \multicolumn{2}{|c|}{ Interval } & \multirow{2}{*}{$x_{j}$} & $n_{j}$ & $x_{j}$ & $p_{j}$ \\
\cline { 1 - 3 } & Origin & End & & & & \\
\hline 1 & 45.719 & 54.281 & 50.000 & 2 & -4.027 & 0.004 \\
\hline 2 & 54.281 & 62.842 & 58.561 & 12 & -3.027 & 0.027 \\
\hline 3 & 62.842 & 71.403 & 67.122 & 31 & -2.027 & 0.069 \\
\hline 4 & 71.403 & 79.964 & 75.683 & 88 & -1.027 & 0.195 \\
\hline 5 & 79.964 & 88.525 & 84.244 & 189 & -0.027 & 0.419 \\
\hline 6 & 88.525 & 97.086 & 92.805 & 84 & 0.973 & 0.186 \\
\hline 7 & 97.086 & 105.647 & 101.366 & 25 & 1.973 & 0.055 \\
\hline 8 & 105.647 & 114.208 & 109.927 & 13 & 2.973 & 0.029 \\
\hline 9 & 114.208 & 122.769 & 118.489 & 3 & 3.973 & 0.007 \\
\hline 10 & 122.769 & 131.330 & 127.050 & 3 & 4.973 & 0.007 \\
\hline 11 & 131.330 & 139.891 & 135.611 & 1 & 5.973 & 0.002 \\
\hline $\mathrm{S}$ & & & & 451 & & 1 \\
\hline
\end{tabular}

The distribution of the statistical value for each group of defects of the pavement was checked in the STATISTICA package. It has been established that the distribution of all samples belongs to a distribution law close to normal, which makes it possible to establish the relationship between the road speed and the presence (absence) of a defect in the road pavement.

As one of the main characteristics of the assessment of operational condition of the pavement is the provision of estimated speed, the amount by which the speed has changed after bringing the road pavement to the norma- tive excellent operational condition is characterized by the change of speed:

where $V_{1} u V_{2}$ are the speed in the section before and after repair works.

$K=V_{2} / V_{1}$

The calculation of the coefficient of change of speed is done based on the generalized weighted average speed of light vehicles for a group of sections with identical defects in the pavement. The results of the calculations are presented in Table 4.

It is also possible to use the International Roughness Index (IRI) to assess the evenness and roughness of the pavement. As the use of road diagnostic tools based on

Table 4: Coefficient of improvement of service performance and traffic safety

\begin{tabular}{|c|c|c|c|}
\hline \multirow{2}{*}{ Characteristic of a defect } & \multicolumn{2}{|c|}{$\begin{array}{c}\text { Average } \\
\text { speed, } \mathrm{km} / \mathrm{h}\end{array}$} & \multirow{2}{*}{$\begin{array}{l}\text { Coeffi- } \\
\text { cient } \mathrm{K}\end{array}$} \\
\hline & $\begin{array}{l}\text { before } \\
\text { repair }\end{array}$ & $\begin{array}{c}\text { after } \\
\text { repair }\end{array}$ & \\
\hline $\begin{array}{l}\text { Cross and longitudinal } \\
\text { with opening width up to }\end{array}$ & 84.29 & 84.92 & 1.0075 \\
\hline $\begin{array}{l}\text { Cross and longitudinal cracks, } \\
\text { with opening width up to } 5 \mathrm{~mm}\end{array}$ & 84.24 & 85.29 & 1.0125 \\
\hline $\begin{array}{l}\text { Cross and longitudinal cracks, } \\
\text { with opening width up to } 10 \mathrm{~mm}\end{array}$ & 83.13 & 84.88 & 1.0211 \\
\hline $\begin{array}{l}\text { Cross and longitudinal cracks, } \\
\text { with opening width more } \\
\text { than } 10 \mathrm{~mm}\end{array}$ & 83.35 & 85.41 & 1.0248 \\
\hline $\begin{array}{c}\text { Single potholes on pavement } \\
\text { containing organic binder } \\
\text { (distance between potholes more } \\
\text { than } 20 \mathrm{~m} \text { ) }\end{array}$ & 76.92 & 87.59 & 1.1388 \\
\hline $\begin{array}{c}\text { Single potholes on pavement } \\
\text { containing organic binder } \\
\text { (distance between potholes } \\
10-20 \mathrm{~m} \text { ) } \\
\end{array}$ & 74.70 & 87.25 & 1.1681 \\
\hline $\begin{array}{l}\text { Infrequent potholes in the same } \\
\text { cases (distance } 4-10 \mathrm{~m} \text { ) }\end{array}$ & 67.55 & 87.03 & 1.2884 \\
\hline $\begin{array}{l}\text { Frequent potholes in the same } \\
\text { cases (distance } 1-4 \mathrm{~m} \text { ) }\end{array}$ & 59.97 & 86.77 & 1.4469 \\
\hline
\end{tabular}

IRI is just beginning in the Russian Federation, it is not possible to use the indicator IRI to predict the changes in the operational condition of the pavement at this stage of the study due to the lack of sufficient statistical measurements. In the future, the methodology will be adapted to the possibility of using international indicators for assessing the operational reliability of roads, road quality and safety.

\section{Application of the graphic-analytical method of estimating the speed}

The use of the graphic-analytical method of analyzing and estimating the change of speed is justified by the fact that firstly the method is simple and visual, secondly 
it is best suited for displaying and analyzing linear dependencies and thirdly it is most often used in road construction practice.

At the present time the following tasks of road construction are solved using the graphic-analytical method (Rosavtodor 2002; Yarmolinsky, Lopashuk, V., Lopashuk A. 2014; Kamenchukov, Yarmolinskiy, Krivko, 2016; Lempert, Sidorov, Zhukov, Nguyen, 2016; Hauser, Ševelová, Matula, Zedník, 2018):

- Diagnosis and certification of roads (Rosavtodor 2002; Yarmolinsky, Lopashuk, V., Lopashuk A. 2014; Lempert, Sidorov, Zhukov, Nguyen, 2016);

- Assessment of provision of estimated road speed (Rosavtodor 2002);

- Assessment of road accident and safety rate: a diagram of accident rates, a diagram of road safety factor (Rosavtodor 2002; Kamenchukov, Yarmolinskiy, Krivko, 2016; Hauser, Ševelová, Matula, Zedník, 2018);

- Scheduling and optimization of excavation: calendar schedules of works; distribution diagrams of earth masses; diagrams of the need for resources, mechanisms and labor resources (Kamenchukov, Yarmolinskiy, Krivko, 2016; Lempert, Sidorov, Zhukov, Nguyen, 2016);

- Assessment of the environmental impact on the road (Lempert, Sidorov, Zhukov, Nguyen, 2016; Hauser, Ševelová, Matula, Zedník, 2018).

We took as a basis the principle of plotting a diagram of provision of the estimated speed, which means that all factors affecting the speed of the vehicle on the road operate independently of each other.

Thus, to assess the speed of traffic on the road, the road is divided into several sections of different lengths, all along which one or several conditions affect the change of speed. The condition that has the greatest impact on the change of speed is taken as the resulting factor. If there are no conditions affecting the change of speed on the section, the value of the resulting criterion of the change of speed on the section is assumed equal to 1. An example of plotting the diagram of the change of speed is shown in Figure 1.

The result of plotting the diagram (Figure 1) is the determination of the following characteristics:

- Weighted average coefficient of change of speed;

- Maximum coefficient of change of speed.

The weighted average coefficient of change of speed $K_{a v}$ is calculated by the formula:

$K_{a v}=\frac{F_{K}}{L}=\sum_{i=1}^{n}\left(K_{i} l_{i}\right) / L$

where $F_{K}$ is the area of the diagram; $L$ is the length of the road or the total length of the road section on which repairs are planned; $K_{i}$ is the final coefficient of change of speed on the plot of the diagram; $I_{i}$ is the length of the plot of the diagram in which the coefficient $K_{i}$ has a constant value.

As various techniques and technologies of road repair are designed to eliminate various defects, the various options for composing repair work will achieve the best improvement of speed.

It is recommended to determine the best variant of works from the price-quality trade-off (Rosavtodor 2013; Ahmed, Saeed, Murillo-Hoyos, Labi 2017; Takahashi, Kimura, Moriyama, 2017). One can use the cost of work as the cost indicator, and the quality indicator is the resulting weighted average rate of change of speed Kav. Also, when valuing the efficiency of work, one can take into account the criterion of saving the time spent by passengers en route $R_{p}$, which is calculated by formula:

$R_{p}=C_{p} T_{p}\left(1-K_{a v}^{-1}\right)$

where $C_{p}$ is the estimated cost of the passenger hour, thousand rubles/passenger hours; $T_{p}$ is the time spent by the passengers en route during the current year of road operation, passenger hours.

The time spent by the passengers en route is defined as the ratio of the annual volume of passenger traffic to

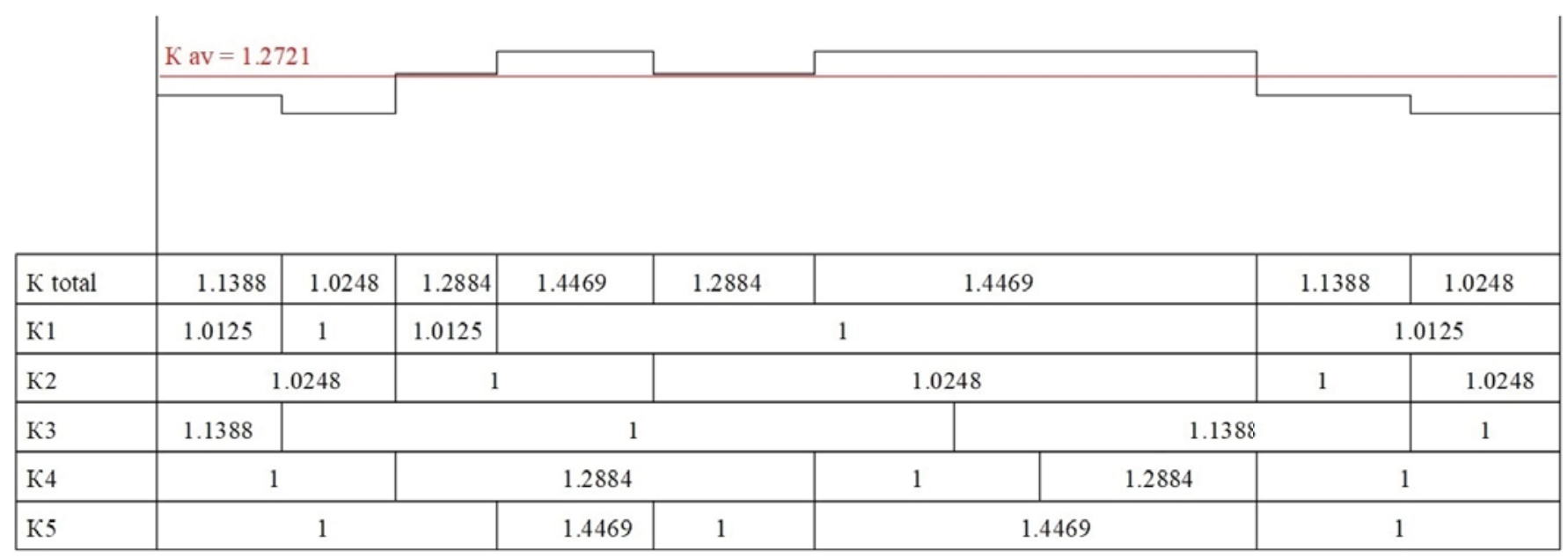

Figure 1. Diagram of the change of speed of vehicles after the repair of highways 
the average speed of the vehicle (passenger car and / or bus) on the examined section of the road.

It follows from formula (9) that the bigger the coefficient of change of speed $K_{a v}$ is, the bigger the economic effect of reducing the cost of being en route is, and the greater the benefits of the road pavement repair works is.

\section{CONCLUSIONS}

Based on the results of observations and statistical processing of the results, the reliable criteria are established for predicting the change of speed of vehicles on the road, on which repair and reconstruction works are planned.

It has also been found that defects on the road pavement significantly affect local changes of the speed of traffic, and the more significant this defect is, the greater is the speed on the road section after its elimination.

The use of the graphic-analytical method of assessing the operational condition of a motor road on the basis of predicting the change of speed of vehicles, depending on the applied repair technology (removing the corresponding pavement defect), allows to determine the priority areas of work.

The use of combined road repair technologies allows to achieve an optimal combination of price and quality of work (improving the service performance of the road speed of traffic) by accurate calculating of the benefits (saving time en route) from the use of appropriate technologies based on the forecast of change of speed on the road.

\section{REFERENCES}

Ahmed, A., Saeed, T.U., Murillo-Hoyos, J., Labi, S. (2017) Pavement repair marginal costs: Accounting for heterogeneity using random-parameters regression. Journal of Infrastructure Systems, 23 (4), article No 04017012. Retrieved from https://doi.org/10.1061/(ASCE)IS.1943555X.0000367.

Chen, Y.-L., Lin, J.-D. (2013) The study of HDM-4 applied in Taiwan area national freeway maintenance and management. Advanced Materials Research, 723, pp. 923-930

Cubero-Fernandez, A., Rodriguez-Lozano, F.J., Villatoro, R., Olivares, J., Palomares, J.M. (2017) Efficient pavement crack detection and classification. Eurasip Journal on Image and Video Processing, 2017 (1), article No 39. Retrieved from https://doi.org/10.1186/s13640017-0187-0

Hauser, J., Ševelová, L., Matula, R., Zedník, P. (2018) Optimization of low volume road pavement design and construction. Journal of Forest Science, 64 (2), pp. 7485. Retrieved from https://doi.org/10.17221/109/2017JFS
Kamenchukov A.V. (2015) Evaluation of the quality of individual works of repair of roads covering [Otsenka kachestva otdel'nykh rabot po remontu pokrytiy avtomobil'nykh dorog]. Far East: Problems of development of architectural-building and road-transport complex [Dal'niy Vostok: Problemy razvitiya arkhitekturno-stroitel'nogo i dorozhno-transportnogo kompleksa]. Khabarovsk. (2015). Vol. 15, 29-33.(in Russian)

Kamenchukov A. V. YArmolinskiy V.A. Krivko E.V. (2016). The impact of the initial information on the quality of the design construction and repair of roads [Vliyanie iskhodnoy informatsii na kachestvo proektirovaniya stroitel'stva i remonta avtomobil'nykh dorog]. PNU, Khabarovsk. (in Russian)

Khan, M.U., Higgins, P.J. (2015) A comprehensive analysis for obtaining consistent hdm-4 results: Case study with a local council in Australia. International Journal of Pavement Research and Technology, 8 (2), pp. 123-130.

Lempert, A.A., Sidorov, D.N., Zhukov, A.V., Nguyen, G.L. (2016) A combined work optimization technology under resource constraints with an application to road repair. Automation and Remote Control, 77 (11), pp. 1883-1893. Retrieved from https://doi.org/10.1134/ S0005117916110011

Onyango, M., Merabti, S.A., Owino, J., Fomunung, I., Wu, W. (2018) Analysis of cost effective pavement treatment and budget optimization for arterial roads in the city of Chattanooga. Frontiers of Structural and Civil Engineering, 12 (3), pp. 291-299. Retrieved from https://doi. org/10.1007/s11709-017-0419-5

Ouma, Y.O., Hahn, M. (2017) Pothole detection on asphalt pavements from 2D-colour pothole images using fuzzy c-means clustering and morphological reconstruction. Automation in Construction, 83, pp. 196-211. Retrieved from https://doi.org/10.1016/j.autcon.2017.08.017

Radovskiy B.S. (2006) The problem of increasing the durability of pavements and methods of its solutions in the USA. Internet Laboratories, Inc., USA: Series: Road Construction Equipment, (2006), 108-119.

Rosavtodor (Federal Road Agency of the Russian Federation) (2002). ORR 218.0.006 (2002) Rules for diagnosis and assessment of the state of highways (instead of DDC 6-90) [ODN 218.0.006 Pravila diagnostiki i otsenki sostoyaniya avtomobilnykh dorog (vzamen VSN 6-90)]. Moscow. (in Russian)

Rosavtodor (Federal Road Agency of the Russian Federation) (2013). ORR 218.2.028 (2013) Methodical recommendations on the feasibility of options compared pavements [ODM 218.2.028 Metodicheskie rekomendatsii po tekhniko-ekonomicheskomu sravneniyu variantov dorozhnykh odezhd]. Moscow. (in Russian)

Samuel Labi, Kumares C. Sinha. (2003) Life-Cycle Evaluation of Highway Pavement Preventive Maintenance. Transportation Research Board. TRB 2003 
Sayers M.W. (1986) Guidelines for conducting and calibrating road roughness measurements. World Bank Technical Paper Number 46, 1986.

Surbakti, M., Doan, A. (2018) Priority of road maintenance management based on halda reading range on NAASRA method. IOP Conference Series: Materials Science and Engineering, 309 (1), article No 012114. Retrieved from https://doi.org/10.1088/1757-899X/309/1/012114

Takahashi, K., Kimura, S., Moriyama, M. (2017) The relationship between damages in road pavement and customer feedback. Life-Cycle of Engineering Systems: Emphasis on Sustainable Civil Infrastructure - 5th International Symposium on Life-Cycle Engineering, IALCCE 2016, pp. 1580-1588.
Venttsel, E.S., Ovcharov, L.A. (1991) The theory of random processes and its engineering applications. Science, Moscow, $384 \mathrm{p}$.

Yarmolinsky, V.A., Lopashuk, V.V., Lopashuk A.V. (2014) Innovative technology of video certification of roads using geographic information systems. Transport construction, 7, pp 6-9.

Yogesh, U.S, Jain, S.S., Devesh, T. (2016) Adaptation of HDM-4 Tool for Strategic Analysis of Urban Roads Network. Transportation Research Procedia, 17, pp. 71-80. 